\title{
The Mitigation of Emotional Distress Damages
}

\author{
Eugene Kontorovich $\dagger$
}

As tort liability for emotional distress has expanded, courts have failed to develop concomitant rules governing the mitigation of emotional injuries. The liberalization of emotional distress recovery has given rise to a vigorous debate over whether such damages promote fairness and economic efficiency or whether they instead result in overcompensation to plaintiffs and threaten to burden defendants with "potentially infinite liability beyond any rational relationship to their culpability." But neither side in this controversy has considered what the absence of mitigation standards shows about the desirability of emotional distress liability.

The absence of mitigation rules means that tort liability for emotional injuries creates moral hazard problems that tend to result in inefficiently low levels of post-injury care by plaintiffs and systematic overcompensation. For example, if psychiatric treatment might reduce or eliminate a plaintiff's emotional distress, the plaintiff might nonetheless forgo such treatment if he knows that the defendant will be liable for the full, unmitigated level of distress. Looking at emotional distress law from the mitigation perspective reveals that some of the rules governing emotional distress liability may exacerbate the moral hazard. For example, in the absence of a mitigation rule, the requirement in some torts that plaintiff must have "severe" distress may actually give plaintiff a disincentive to try to reduce his damages. It also shows that the most serious emotional injuries do not create the most moral hazard, suggesting that popular tort reform measures like damage caps would do little to reduce the overcompensation for emotional distress attributable to moral hazard.

There are good reasons for the absence of mitigation rules for emotional distress. Possible standards for emotional distress mitigation would either be difficult for courts to administer or would fail to satisfy the mitigation goal of joint-cost minimization. ${ }^{2}$ Because of the

$\dagger$ B.A. 1996, The University of Chicago; J.D. Candidate 2001, The University of Chicago.

1 Dillon $v$ Legg, 68 Cal 2d 728, 441 P2d 912, 928 (1968) (Burke dissenting) (dissenting from landmark case allowing recovery to mother for emotional distress caused by seeing her child killed by a negligent motorist).

2 Joint-cost minimization requires each actor to reduce the total cost of the injury, sometimes even when doing so increases his share of the total cost. See Charles J. Goetz and Robert E. Scott, The Mitigation Principle: Toward a General Theory of Contractual Obligation, 69 Va L Rev 967, 973-76 (1983) (arguing that a mitigation rule in contracts generally stands for a joint- 
difficulty of creating satisfactory mitigation rules for emotional distress, courts must limit moral hazard in emotional distress cases by limiting the scope of liability or recovery.

Courts wishing to limit moral hazard in emotional distress torts, a form of third-party insurance, should look to the methods used by first-party insurers, who first coined the term "moral hazard." However, the first-best methods, like copayments and deductibles, do not translate well into the third-party insurance context because the total amount plaintiff can recover is endogenous to the litigation process. A combination of damage caps and floors, or workmen's compensationstyle damage schedules, could help control moral hazard when the emotional distress recovery is an element of consequential damages. However, such legislative solutions would be incoherent when applied to emotional distress as an independent tort. In such actions, the best way for courts to control moral hazard would be to return to the recently disfavored approach of allowing recovery only in categories of cases where objectively verifiable circumstances, such as a crippling wound, allow courts to infer severe emotional distress with a high degree of confidence.

Part I first describes the contours of emotional distress liability and then explains the mitigation doctrine and its goal of reducing moral hazard. This Part shows that courts have failed to apply mitigation to emotional distress, while applying it to all other areas of tort liability. Part II finds that moral hazard exists in emotional distress liability, resulting in systematic overcompensation. However, this Part shows that the level of hazard varies across the different contexts in which plaintiffs recover for emotional distress.

Part III considers what emotional distress mitigation would look like. This Part rejects the superficially appealing standard of psychiatric or psychotropic mitigation as being unlikely to satisfy the joint-cost minimization criteria in a large number of cases. It also finds unsatisfactory an alternate paradigm, willpower mitigation, whereby plaintiffs must take reasonable efforts to exercise self-control and discipline to reduce their emotional distress. Part IV considers ways courts can reduce the moral hazard inherent in emotional distress damages without a mitigation rule. It suggests limiting the availability of emotional distress damages to objectively defined categories, and eliminating the subjective severity test used by some courts in the tort of negligent infliction of emotional distress. 


\section{EMOTIONAL DISTRESS LIABILITY AND MITIGATION}

\section{A. The Expansion of Emotional Distress ${ }^{3}$ Liability}

The history of emotional distress represents an ongoing attempt by courts to balance the conflicting goals of full compensation and precluding fraudulent or de minimis claims - with the balance shifting ever more towards compensation. Courts began allowing recovery for emotional distress in narrowly defined sets of circumstances at the start of the twentieth century. Since then, the availability of such damages has expanded greatly. ${ }^{5}$ But the inchoate, subjective nature of such claims has created significant problems of measurement and proof. Thus, at each stage of the liability expansion, courts have attempted to limit recovery to categories of cases where the emotional distress seems most likely to be genuine and substantial, such as where the distress flows from a physical injury to a plaintiff. ${ }^{6}$ These limitations have been criticized for being arbitrarily over- and underinclusive: some apparently deserving plaintiffs would be denied recovery because the injury did not fall within the category, while plaintiffs with less intuitively appealing claims could recover. For example, the physical injury requirement could deny recovery to a plaintiff negligently

3 These damages go under a bewildering variety of names: "emotional distress," "emotional anguish," "severe emotional distress," "mental distress," "mental disturbance," "emotional disturbance," and "mental anguish." See, for example, Clohessy v Bachelor, 237 Conn 31, 675 A2d $852,853,855-56,859,863$ (1996) (using interchangeably all of the above terms to describe psychic injury suffered by mother and child as a result of seeing mother's other child fatally injured in an automobile accident). There are apparently no differences either in medicine or law between such terms. See Douglas J. Whaley, Paying For the Agony: The Recovery of Emotional Distress Damages in Contract Actions, 26 Suffolk U L Rev 935, 939 n 15 (1992) (considering to what extent recovery for emotional distress damages should be permitted in contract suits through, in part, an examination of such damages in tort law). Also, the distinction between emotional or mental damages and "pain and suffering" has caused confusion, see id, though these are in fact distinct categories. "Pain and suffering" generally denotes the actual pain caused by physical injury, whereas mental distress is a higher-order cognitive reaction to physical or other injury. See Steven P. Croley and Jon D. Hanson, The Nonpecuniary Costs of Accidents: Pain-And-Suffering Damages in Tort Law, 108 Harv L Rev 1785, 1789 n 11 (1995) (distinguishing among various "species of nonpecuniary losses" recognized by courts).

4 See Nancy Levit, Ethereal Torts, 61 Geo Wash L Rev 136, 142 nn 29-30, 32 (1992) (citing cases).

5 See Payton v Abbott Labs, 386 Mass 540, 437 NE2d 171, 176-78 (1982) (examining the development of emotional distress damages); Levit, 61 Geo Wash L Rev at 140-46 (cited in note 4) (chronicling the growth of emotional distress liability); Whaley, 26 Suffolk U L Rev at 940-46 (cited in note 3) (same); Stuart M. Speiser, et al, 4 The American Law of Torts ch 16 (Law Co-op 1987) (describing the variety of situations where emotional distress damages have been allowed).

6 See Metro-North Commuter Railroad Co v Buckley, 521 US 424, 433 (1997) (explaining that common law courts created categories to limit emotional distress recovery because of, among other reasons, the "special 'difficult[y] for judges and juries' in separating valid, important claims from those that are invalid and or 'trivial'"); Payton, 437 NE2d at 178-79 (describing problems involved in dealing with emotional distress damages stemming from difficulty in determining which emotional injuries were "real" and "serious"). 
misdiagnosed with AIDS, but allow recovery to one with a paper cut. As a result, courts have abandoned many of the doctrinal limitations, and gradually moved closer to recognizing a general legally protected "interest in personal emotional stability." With negligent infliction of emotional distress torts ("NIED")-actions that could afford the broadest basis of liability - courts continue to struggle to create sensible limits on recovery while avoiding arbitrary limitations.

\section{Emotional distress as part of consequential damages.}

Courts first allowed recovery for emotional distress only when the plaintiff could make out a cause of action for some already recognized tort, usually involving physical injury. ${ }^{8}$ These "parasitic" emotional injury cases reflected a judgment that while the subjectivity of emotional distress damages might encourage false, trivial, and imagined claims, emotional distress was likely to be real and substantial when it resulted from a physical injury. ${ }^{10}$ The physical injury requirement eventually withered, and emotional distress damages have become widely available as an element of consequential damages in any "distinct and independent tort," including purely economic torts." In such cases, plaintiffs can recover even for minor or fleeting distress so long as the "host" injury is substantial.

\section{Intentional infliction of emotional distress ("IIED").}

The creation of the intentional infliction tort in the early $1950 \mathrm{~s}$ enabled plaintiffs to recover for emotional distress absent any other injury. ${ }^{13}$ The intentional infliction tort reflects courts' desire to broaden liability while confining emotional distress recovery to cases where plaintiff will likely have real and severe distress. In IIED, the defendant's intent to cause distress serves as an evidentiary proxy for the

7 Clohessy, $675 \mathrm{~A} 2 \mathrm{~d}$ at 860.

8 See Levit, 61 Geo Wash L Rev at 142 (cited in note 4) (discussing history of parasitic damage rule); John H. Bauman, Emotional Distress Damages and the Tort of Insurance Bad Faith, 46 Drake L Rev 717, 722 (1998) (same).

9 Payton v Abbott Labs, 386 Mass 540, 437 NE2d 171, 176 (1982) (discussing historical development of emotional distress liability that began with parasitic claims).

10 See id (discussing policies behind parasitic recovery cases). See also William Landes and Richard Posner, The Economic Structure of Tort Law 245 (Harvard 1987) (discussing the efficiency of allowing emotional distress damages only when accompanied by physical injury).

11 Pershing Park Villas Homeowners Assoc v United Pacific Insurance Co, 219 F3d 895, 903 (9th Cir 2000) (upholding emotional distress award to real estate developers whose insurance company tortiously denied them liability coverage against suits by disgruntled homeowners).

12 See id at 903-04 (describing California law).

13 See Payton v Abbott Labs, 386 Mass 540, 437 NE2d 171, 177 (1982) (explaining historical genesis of recovery for intentional infliction of emotional distress absent physical harm). The American Law Institute recognized IIED as an independent tort in 1965. See Restatement (Second) of Torts $\$ 46$ (1965). 
existence and severity of the distress itself. ${ }^{14}$ Courts limit liability to instances of "extreme and outrageous conduct" that result in "distress ... so severe that no reasonable man could be expected to endure it." "Still, courts do not simply rely on intent to establish the severity of plaintiffs' distress. The jury must independently determine that plaintiff has in fact suffered severe distress."

\section{Negligent infliction of emotional distress ("NIED").}

The NIED tort represents the current wave of expansion and uncertainty in emotional distress liability. Most jurisdictions allow recovery in at least some categories of cases where defendant's lack of care causes nothing but emotional injury. ${ }^{17}$ But if given its fullest possible scope, NIED would allow plaintiffs to have a cause of action whenever defendant fails to take reasonable care to avoid causing emotional injury. ${ }^{18}$ Because such a broad duty would seem to invite an avalanche of litigation composed largely of nonmeritorious claims, most courts limit recovery to cases with either physical or contextual proxies for severity. ${ }^{19}$ However, "the modern judicial trend is to abolish the physical manifestation requirement and permit a general negligence cause of action for the infliction of serious emotional distress without regard to whether the plaintiff suffered any physical injury as a result." ${ }^{20}$

14 See, for example, Wilkes v Young, 28 F3d 1362, 1366 (4th Cir 1994) (describing common law requirements of IIED); Wilkinson v Downton, 2 QB 61 (1897) (finding defendant liable when he falsely told plaintiff that her husband had been badly injured).

15 Restatement (Second) of Torts $\S 46 \mathrm{cmt}$ j. For example, in one early case, defendant tricked plaintiff into thinking that her hospitalized spouse had died. Id at ill 1.

16 See, for example, Wilkes, $28 \mathrm{~F} 3 \mathrm{~d}$ at 1366 (describing requirement that jury find presence of severe distress).

17 See Paytori v Abbott Labs, 386 Mass 540, 437 NE2d 171, 177 (1982) (noting allowance by most courts of recovery for emotional distress when plaintiff was in "zone of danger"); Bauman, 46 Drake $L$ Rev at 725-26 (cited in note 8) (explaining expansion and retraction of available recovery for emotional distress without physical harm).

18 See Payton, 437 NE2d at 174-75 (explaining dangers of broad NIED actions).

19 See Scott D. Marrs, Mind Over Body: Trends Regarding the Physical Injury Requirement in Negligent Infliction of Emotional Distress and "Fear of Disease" Cases, 28 Tort \& Ins L J 1, 1-2 (1992) (surveying jurisdictions and concluding that an "ebbing majority" requires some physical injury or symptom to maintain an NIED action).

20 Id at 4. See, for example, St Elizabeth Hospital v Garrard, 730 SW2d 649, 654 (Tex 1987) ("[P]roof of physical injury resulting from mental anguish is no longer an element of the common law action for negligent infliction of mental anguish."); Gates v Richardson, 719 P2d 193, 200 (Wyo 1986) (electing not to require that physical harm accompany emotional harm in permitting recovery by mother and siblings who witnessed accident that left child comatose). At least one other jurisdiction (Massachusetts) appears poised to abandon the physical injury requirement. See Kathryn E. Hand and Patricia L. Kelly, Massachusetts Tort Law Manual \$ 6.1.1(3) (Mass CLE 2000) (discussing signs that Supreme Judicial Court might abandon physical injury requirement). 
Moreover, most jurisdictions have carved out certain categories where recovery can be had despite a lack of physical manifestation because the cause of the injury seems likely to result in severe distress. A "strong majority" of courts allow NIED claims without any physical manifestation in "zone of danger" cases, where the defendant's carelessness comes close to physically hurting plaintiff, but in fact does not. ${ }^{21}$ More recently, an increasing number of courts have allowed "bystander" recovery, ${ }^{22}$ where plaintiff witnesses serious physical injury inflicted upon a third party as a result of defendant's negligence, but does not suffer any injury himself. The limits of bystander liability remain unclear, with courts reaching differing conclusions on how closely related the NIED plaintiff must be to the third-party victim, ${ }^{24}$ and whether the plaintiff must visually and contemporaneously perceive the third-party injury.

\section{B. The Mitigation Doctrine}

This Part discusses the doctrinal features and policy motivations of the mitigation rule. Mitigation doctrine prevents a plaintiff from re-

21 Consolidated Rail Corp v Gottshall, 512 US 532,547-48 (1994) (adopting zone of danger test for NIED claims under the Federal Employers Liability Act without any physical manifestation requirement); Payton, 437 NE2d at 177 (asserting that, by 1965, the "strong majority" of American courts had adopted the zone of danger rule).

22 This category of NIED cases began with the watershed case of Dillon v Legg, $68 \mathrm{Cal} 2 \mathrm{~d}$ 728, 441 P2d 912, 920-21 (1968) (allowing mother to recover for distress caused by seeing child run over by car, although mother was never in any physical danger). The California Supreme Court subsequently narrowed Dillon's amorphous "forseeability" standard of liability in Thing $v$ La Chusa, 48 Cal 3d 644, 771 P2d 814, 826 (1989) (concluding that a simple "forseeability" standard "provides virtually no limit on liability for nonphysical harm").

23 See Patrick F.X. Santel, Comment, Bystanders' Negligent Infliction of Emotional Distress Claims in Washington State: Must You Be Present to Win?,23 Seattle U L Rev 769, 779-81 (2000) (surveying jurisdictions and finding that nearly half of American states allow recovery for bystanders who were never themselves imperiled).

24 Many courts only allow recovery for members of victim's immediate family. See, for example, Trombetta $v$ Conkling, 593 NYS2d 670, 671 (App Div 1993) (imposing "immediate family" requirement to deny recovery to victim's niece so as not to "unreasonably extend the limits of defendants' duty" of care), affd 605 NYS2d 678, 626 NE2d 653 (NY 1993). But see Dunphy $v$ Gregor, $136 \mathrm{NJ}$ 99, 642 A2d 372, 380 (1994) (extending recovery to cohabitant fiancée of accident victim because relationship constituted "[a]n intimate familial relationship"). A few states may not require any familial or intimate relationship at all. See, for example, Paugh $v$ Hanks, 6 Ohio St 3d 72, 451 NE 2d 759, 766-67 (Ohio 1983) (refusing to define how closely related a plaintiff must be to a victim to sustain an emotional distress claim).

25 Compare Hegel v McMahon, 136 Wash 2d 122, 960 P2d 424, 429 (1998) (allowing family member to recover when he sees physically injured family member "shortly after [the accident] and before there is substantial change in the [victim's] condition or location"), and Masaki v General Motors Corp, 71 Hawaii 1, 780 P2d 566, 576 (1989) (announcing Hawaii's "same island" rule and allowing a son to recover for emotional distress when the son resided on the same island as his father and saw his father in the hospital after an accident), with Fineran v Pickett, 465 NW2d 662, 663-64 (lowa 1991) (refusing to allow recovery for parents and siblings who arrived at daughter's injury scene two minutes after she had been hit by car). 
covering the portion of his damages that he could have prevented by taking reasonable care after having suffered his injury. It reduces the moral hazard created by tort insurance, whereby plaintiff has reduced incentives to take efficient post-injury care because, absent a mitigation rule, the benefits of such care would accrue to the tortfeasor, who serves as the plaintiff's insurer within the context of the action. This Part shows that while courts apply mitigation throughout torts, and indeed in all damage actions, they have not extended the mitigation principle to emotional distress injuries.

\section{General aspects of the doctrine.}

Under the mitigation rule, an injured party cannot recover for damages that he could have reduced or prevented by exercising reasonable care after sustaining his injury. ${ }^{26}$ The defendant must reimburse the plaintiff for all reasonable expenses incurred in attempting to mitigate his damages, regardless of whether plaintiff's efforts succeed. ". Mitigation differs from doctrines like the "eggshell-skull" rule and contributory negligence because it comes into play once a defendant's liability has been established and only calls into question the appropriate amount of damages. ${ }^{28}$ Mitigation deals only with the plaintiff's conduct after his cause of action accrues and the defendant pleads it as an affirmative defense for which he carries the burden of proof. $^{29}$

A plaintiff satisfies the mitigation rule by taking the steps that an ordinary, reasonable person would take in the same circumstances. In

26 See Jackson v City of Kansas, 263 Kan 143, 947 P2d 31, 36 (1997) ("The law does not penalize [plaintiff's] inaction; it merely does nothing to compensate him for the harm that a reasonable man in his place would have avoided."), quoting with approval, Theis $v$ duPont, Glore Forgan Inc, 212 Kan 301, 510 P2d 1212, 1217-18 (1973).

27 See ECDC Environmental, LC v New York Marine and General Insurance Co, 1999 US Dist LEXIS 15268, *6-7 (S D NY) ("[Plaintiff] was not required to take extraordinary measures to mitigate damages, or even to take measures which in hindsight might have been more successful ... as long as [plaintiff's] efforts were reasonable, the cost associated with [plaintiff's] efforts is reimbursable.").

28 The eggshell skull rule applies to the plaintiff's preexisting physical condition. See Munn $v$ Algee, 924 F2d 568, 576 (5th Cir 1991). Contributory negligence applies to the plaintiff's conduct leading up to the injury. See Munn v Southern Health Plan, 719 F Supp 525, 527 (N D Miss 1989).

29 Courts and commentators commonly, but inaccurately, describe mitigation as a "legal obligation," see, for example, Marvin A. Chirelstein, Concepts and Case Analysis in the Law of Contracts 153 (Foundation 3d ed 1998), or a "duty" that the law "imposes" upon the plaintiff, see, for example, Richard A. Epstein, Torts $\$ 17.7$ (Aspen 1999). However, mitigation is not a legal duty, since its neglect "does not create a right of action in any other person." W.E. Shipley, Annotation, Duty of Injured Person to Submit to Nonsurgical Medical Treatment to Minimize Tort Damages, 62 ALR 3d $70 \S 3 \mathrm{n} 29$ (1975). "[T]he doctrine of avoidable consequences" may be the superior term, see Jackson, $947 \mathrm{P} 2 \mathrm{~d}$ at 36 (supporting "avoidable consequences" terminology), although "duty to mitigate" appears to be more widely used. 
the context of negligence, Judge Learned Hand defined a reasonable precaution as one whose cost is less than or equal to the expected cost of the accident. ${ }^{30}$ In theory, this definition works as well for mitigation as for liability. ${ }^{31}$ However, hard cases cannot be reduced to an algebraic formula, especially when the "care" involves risking one's life rather than taking a simple precaution such as installing safety devices. For example, a surgical procedure could have a positive expected value, but still have a 10 percent chance of killing the plaintiffpatient. $^{32}$ Indeed, for a risk-averse plaintiff, this medical procedure would not be worthwhile. Courts hold that it is ipso facto reasonable for plaintiffs to refuse treatments that would meet the Hand test if they create "peril to life, however slight, and undue risks to health, and anguish that goes beyond the bounds of reason.","33

2. Reducing moral hazard - the policy informing the mitigation doctrine.

The mitigation doctrine tries to curb ex post moral hazard-the tendency of people with insurance to suffer greater losses than the uninsured. ${ }^{34}$ The concept translates directly to lawsuits, for when a defendant becomes legally liable for the plaintiff's injuries, he effectively becomes the plaintiff's insurer in the context of the action. ${ }^{35}$ Thus, without a mitigation rule, plaintiffs would have a perverse incentive to sit back and let their damages mount, even though they could stanch the loss by exercising reasonable care. ${ }^{36}$ As a result, plaintiffs would be overcompensated in the absence of a mitigation rule: they would receive more in damages than they would ex ante wish to purchase as insurance for the same injury. The greater the ex post control the insured can exercise over the amount of loss, the greater the moral haz-

30 See United States $v$ Carroll Towing Co, 159 F2d 169, 172 (2d Cir 1947).

31 See Goetz and Scott, 69 Va L Rev at 973-74 (cited in note 2) (developing joint-cost minimizing model of avoidable consequences rule in contractual breach context).

32 See Epstein, Torts $\$ 17.7$ at 448 (cited in note 29).

33 See, for example, Cannon v New Jersey Bell Telephone, 219 NJ Super 304, 530 A2d 345, 350-52 (NJ Super App Div 1987) (holding reasonable as a matter of law plaintiff's decision not to undergo doctor recommended urethral surgery to remove blockage that had 93 percent chance of success but also had up to 15 percent chance of rendering plaintiff impotent), quoting Budden $v$ Goldstein, 43 NJ Super 340,128 A2d 730 (NJ Super App Div 1957).

34 See Tom Baker, On the Genealogy of Moral Hazard, 75 Tex L Rev 237, 238-39 (1996) (defining and describing moral hazard).

35 See George L. Priest, The Current Insurance Crisis and Modern Tort Law, 96 Yale L J 1521,1553 (1987) ("[V]ictim moral hazard is as serious a problem in a third-party [tort] context as in a first-party context. Preferences for extra visits to the doctor, prolonged hospitalization, or more advanced forms of medical treatment do not diminish because the source of the injury is a third-party defendant.").

36 See id at 1547. 
ard. ${ }^{37}$ The mitigation rule, by forcing plaintiffs to act as if their losses were not insured, "encourage[s] plaintiffs to reduce the societal costs of their injuries." ${ }^{38}$ So a properly functioning mitigation rule mimics a situation in which the plaintiff owns his full loss; mitigation makes plaintiffs internalize the costs of their post-injury conduct.

Nineteenth-century insurers coined the phrase "moral hazard," and the insurance market remains the best place to study the problem and its possible solutions. Ideally, an insurer would contractually condition reimbursement on the exercise of care by the insured. However, moral hazard problems become particularly acute when the insurer cannot observe care at all or cannot do so efficiently. ${ }^{40}$ Insurers respond to the unobservability problem by offering only partial coverage $^{41}$ or no coverage at all, or by raising premiums. First-party insurance also relies on deductibles and copayments to reduce moral hazard. ${ }^{42}$ Deductibles and copayments force claimants to pay either a fixed sum or a percentage of their loss. All these strategies reduce available coverage, because when recovery cannot be conditioned on care, moral hazard can only be reduced or avoided by giving the insured a direct stake in the size of his loss.

\section{The universal application of the mitigation rule.}

The important economic function of the mitigation doctrine explains its complete acceptance by courts and uniformly favorable treatment by scholars. It is the "universal common law rule" in torts, and applies with equal vigor in contract $^{44}$ and statutory actions. Courts apply it to legislatively created causes of action, such as anti-

37 See Kenneth J. Arrow, Uncertainty and the Welfare Economics of Medical Care, $53 \mathrm{Am}$ Econ Rev 941, 961 (1963) (explaining that moral hazard arises when the insured can have some control over his amount of loss, and giving example of reluctance to use medical services after an injury).

38 Munn v Algee, 924 F2d 568, 576-77 n 16 (5th Cir 1991).

39 Baker, 75 Tex L Rev at 250-52 (cited in note 34) (recounting the genesis of the term "moral hazard").

40 See Steven Shavell, On Moral Hazard and Insurance, 93 Q J Econ 541, $544-50$ (modeling insurance market when insurer is not able to observe the behavior of the insured).

41 See id at 546 (arguing that optimal level of coverage under conditions of asymmetric information is always positive).

42 See Priest, 96 Yale L J at 1548 (cited in note 35) (explaining internal mechanisms for reduction of moral hazard in the market insurance context).

43 Epstein, Torts at $\$ 17.7$ (cited in note 29).

44 See Goetz and Scott, 69 Va L Rev at 967 (cited in note 2) ("The duty to mitigate is a universally accepted principle of contract law.").

45 See, for example, Roger D. Colton and Doug Smith, The Duty of a Public Utility To Mitigate "Damages" from Nonpayment through the Offer of Conservation Programs, 3 BU Pub Int L J 239,248-49 (1993) ("There are few principles in the law of remedies as well established as that of a claimant's duty of mitigation."). 
trust, ${ }^{46}$ takings, ${ }^{47}$ and environmental law. ${ }^{48}$ Indeed, with only one narrow set of exceptions, "[ $t$ ]he principle of 'avoidable consequences' ... finds its application in virtually every type of case in which the recovery of a money judgment or award is authorized."

\section{Never the Twain Shall Meet?}

Despite the ubiquitous use of mitigation in determining damages, courts have neglected to apply the rule to emotional distress. ${ }^{50}$ The question of whether a plaintiff failed to mitigate emotional distress damages has only been discussed in roughly a dozen or so reported decisions. ${ }^{\text {s1 }}$ No court has created an explicit affirmative exception for

46 See, for example, Young $v$ Whidbey Island Board of Realtors, 96 Wash 2d 729, 638 P2d 1235, 1237-38 (1982) (en banc) (holding that mitigation rules govern damages under the state's Unfair Business Practices Act, even though such suits are "largely divorced from [their] original grounding in the law of torts").

47 See State v Pahl, 254 Minn 349, 95 NW2d 81, 91 (1959) (applying mitigation rule to owner of condemned house).

48 Intel Corp v Hartford Accident and Indemnity Co, 692 F Supp 1171, 1191 (N D Cal 1989), revd in part on other grounds, 952 F2d 1551 (9th Cir 1991) (applying duty to mitigate in cases involving cleanup of hazardous waste).

49 Kelley $v$ Chicago Park District, 409 Ill 91, 98 NE2d 738, 742 (1951), quoting with approval, Dresskell $v$ City of Miami, 153 Fla 90, 13 S2d 707, 709 (1943) (holding that mitigation for wrongful termination applies not only to contractual employment, but also to public officials whose employment terms are determined by law).

50 This Comment deals only with mitigating emotional distress damages themselves. When a tortiously created situation creates a variety of injuries, and the plaintiff has it in his power to remedy the underlying source of his physical, economic, and emotional injuries but refuses to do so, the defense of mitigation will be available. But this issue is distinct from - and easier thanmitigation directed at the amount of emotional distress itself. See, for example, Rogan $v$ Lewis, 975 F Supp 956, 966 n 14 (S D Tex 1997) ("Had plaintiff pursued an appeal [for reinstatement as a teacher] with the Texas Education Agency, she might have been able to mitigate some or all of her emotional distress damages that may flow from the due process deprivation."); Chuy v Philadelphia Eagles Football Club, 431 F Supp 254, 257, 263-64 n 15 (E D Pa 1977) (upholding a jury instruction on mitigation in an intentional infliction case brought by an athlete who saw on television the team doctor erroneously claim that he had a life threatening disease, and who as a result experienced a six-month "period of extreme emotional anguish and torment during which he anticipated his death," yet failed to take tests to find out whether he really had the condition), affd 595 F2d 1265, 1276 (3d Cir 1979) (en banc).

51 A significant number of these cases avoid any substantive discussion of the mitigation issue by finding that plaintiff's emotional distress made him too upset to be able to mitigate his distress. See Botek v Mine Safety Appliance Corp, 531 Pa 160,611 A2d 1174, 1177 n 2 (1992) ("It is clear that where a claimant's rejection of [psychiatric] treatment is part of his emotional injuries, he may recover damages in spite of his failure to receive treatment."); Cannon v New Jersey Bell Telephone, 219 NJ Super 304, 530 A2d 345, 351-52 (NJ Super App Div 1987) (holding that teenage boy, suffering possibly permanent urethral damage after colliding with defendant's dangling telephone wire, who refused psychiatric counseling recommended by his doctor "should not be precluded from recovering full damages because of a psychological state which led him to reject any needed counseling"), citing with approval, Feld v Merriam, 314 Pa Super 414, 461 A2d 225, $234 \mathrm{n} 12$ (1983) (holding that plaintiff is not "precluded from recovering compensatory damages" although he did not mitigate damages by undergoing psychiatric counseling because his "general rejection of psychiatric treatment is a manifestation of his emotional injuries"), revd

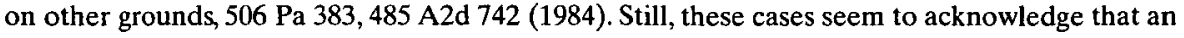


emotional distress, but a de facto exception seems to obtain. ${ }^{52}$ Commentators appear to have wholly ignored the issue. The lack of authority and analysis results in large differences in how these few decisions treat the mitigation defense. Only two obscure cases, both in local trial courts, have reduced a plaintiff's recovery for refusing to mitigate emotional distress damages. ${ }^{53}$ On the other hand, at least one court seems to think that emotional distress might be exempt from the mitigation rule, ${ }^{54}$ though no court has actually held that mitigation does not apply. Two other cases suggest that mitigation might be applicable to emotional distress, but refuse to establish a "reasonableness" test based on seeking psychiatric treatment. ${ }^{\text {ss }}$

\section{EMOtional Distress LiabiLITy Without A Mitigation RulE RESULTS IN SYSTEMATIC OVERCOMPENSATION}

From a policy perspective, the mitigation rule should only apply to emotional distress liability if two conditions are satisfied: (1) emotional distress liability must create the moral hazard problems common to all other forms of tort liability; and (2) the mitigation rule

emotional distress award could be reduced for failure to mitigate in the proper circumstances.

52 The reporters contain only one (very recent) case where the mitigation question has reached a jury. See Musa v Jefferson County Bank, 233 Wis 2d 241, 607 NW2d 349, 352 n 7 (Wis Ct App 2000) (describing jury instruction on "duty to mitigate damages for emotional distress," which tells jury that injured plaintiff must use ordinary care in seeking and submitting to "medical treatment"), pet for rev granted, 237 Wis 2d 251, 616 NW2d 114 (2000). See also Salas v United States, 974 F Supp 202, 211 (W D NY 1997) (noting the court could only locate a single case that "address[es] the duty to mitigate damages where the plaintiff's injury is psychiatric in nature").

53 Both cases involved plaintiffs who refused psychiatric attention and medication to treat their distress, against the advice of their attending physicians. See Tucker $v$ Town of Branford, 1998 Conn Super LEXIS 1139, *14-15, 22-23 (plaintiff, who suffered "severe shock to her nervous system" as result of a minor auto accident, but who refused doctor recommended medication therapy that would have cured her within six months, could only recover for six months of distress); Skaria v New York, 110 Misc 2d 711, 442 NYS2d 838, 842 n 1 (NY Ct Cl 1981) (holding, in landlord liability suit, that rape victim failed to mitigate her emotional distress by not seeking treatment for distress, and finding unreasonable plaintiff's "excuse" of wanting to "conceal her rape"). These two opinions assume, without any analysis, that mitigation applies to emotional distress as surely as it does to any other damages. See Tucker, 1998 Conn Super LEXIS 1139 at *2223 (applying mitigation doctrine when plaintiff refused to seek psychiatric treatment); Skaria, 442 NYS2d at 842 ("[C]laimants are bound by the proposition of law that an injured plaintiff has an affirmative duty to mitigate damages.").

54 See Zerilli $v$ New York City Transit Authority, 973 F Supp 311, 323 (E D NY 1997) (suggesting in dicta that there is "no authority" to support a mitigation defense for emotional distress damages). See also Whaley, 26 Suffolk U L Rev at $951 \mathrm{n} 73$ (cited in note 3) (mentioning in passing that "mitigation [is] impossible" for emotional distress injuries).

55 See Baker v Dorfman, 1999 US Dist LEXIS 4451, *17 (S D NY) (holding that plaintiff's "desire not to take medication, standing alone, does not support [defendant's] argument" that plaintiff did not mitigate his distress), affd on other grounds, 2000 US App LEXIS 22798 (2d Cir); Dohman v Richard, 282 S2d 789, 793-94 (La App 1973) (holding that requirement of mitigation of emotional injuries does not extend to doctor recommended "psychiatric therapy" in the form of electroshock). 
must solve the moral hazard problem. This Part begins by considering "incommensurability" arguments that might suggest moral hazard would not arise in emotional injuries. It explains that while money may not replace injured emotions, it can substitute for them, and thus may make plaintiffs indifferent, ex ante, between distress and some amount of damages. Moral hazard exists for emotional distress liability and may be quite high in some situations. This Part goes on to examine whether private incentives reduce the moral hazard and make legal intervention less necessary.

\section{A. Why Moral Hazard Exists for Emotional Injuries}

In general, not having a mitigation requirement results in excessive compensation from an ex ante perspective - that is, more compensation than the insureds would be willing to pay for if they were to contract for it in advance. ${ }^{56}$ Emotional distress liability will create moral hazard because the "insured" victim can exercise some degree of control over the ex post size of the injury-a defining condition of moral hazard. Given that there is no ceiling on common law tort recovery, emotional distress victims "would have an incentive to exacerbate the extent of their damages in order to recover more than their actual losses - the ex post species of moral hazard." ${ }^{\text {,7 }}$ Victims might be able to control their degree of distress in numerous ways, from medication to keeping a "stiff upper lip." lieve that there is no reason moral hazard would vanish when the insured loss is emotional, and attribute the lack of first-party insurance for nonpecuniary injuries in general to severe moral hazard problems.

Indeed, emotional distress may create more moral hazard than other injuries. Moral hazard is a problem of "hidden action," based on the difficulty of monitoring the victim's level of care. ${ }^{60}$ Most courts do

56 See Priest, 96 Yale L J at 1547 (cited in note 35) (arguing that ex post moral hazard created by insurance for nonpecuniary loss results in higher compensation than victims would wish to purchase in advance).

57 Croley and Hanson, 108 Harv L Rev at 1849 (cited at note 3). There is also another type of moral hazard, ex ante moral hazard, where a person values emotional stability at less than the likely legal compensation. See id. This Comment does not consider those problems because they would not be addressed by any mitigation rule.

58 See Part III.B. The amount of control victims have will likely vary depending on the nature and cause of the distress.

59 See, for example, Croley and Hanson, 108 Harv L Rev at 1848-51 (cited in note 3) (ascribing lack of nonpecuniary loss insurance to difficulties in evaluating the severity of the loss); Priest, 96 Yale L J at 1547, 1553 (cited in note 35) (discussing the existence of a moral hazard given insurance for pain and suffering, and considering this as possible explanation for the fact that insurance companies do not write policies for nonpecuniary losses).

60 See Douglas G. Baird, Robert H. Gertner, and Randal C. Picker, Game Theory and the Law 153 (Harvard 1994) (describing the "hidden action problem" of moral hazard). Hidden ac- 
not require any medical or psychiatric evidence to establish an emotional distress claim, allowing the jury to base its determination solely on plaintiff's testimony about his subjective state. ${ }^{61}$ Because emotional distress takes place entirely within the plaintiff's mind, it could be difficult to observe or verify whether he took appropriate ex post care. ${ }^{62}$

\section{B. Incommensurability?}

It may seem counterintuitive that a plaintiff would, in the absence of a mitigation rule, willingly forgo opportunities to reduce his own suffering. But mitigation always entails some cost, and the costlier the mitigation, the greater the moral hazard. ${ }^{6.3}$ Even small efforts like visiting a doctor have positive costs, even if only the opportunity costs of time, like sitting in a doctor's waiting room. Why undertake costly actions whose financial benefits will be captured by the defendant? Furthermore, people may have strong idiosyncratic preferences. For example, plaintiffs might refuse medical care out of religious scruple ${ }^{64}$ or a distrust of doctors.

However, the mitigation rule assumes that the extra emotional distress created by not mitigating can actually be made good through monetary compensation. ${ }^{65}$ The "incommensurability" theory holds that money may compensate for emotional injury, but not fully. Thus an award equal to the "value" of plaintiff's distress might make him less than 100 percent whole. Of course, this slippage would likely vary in degree across types and severity of emotional distress. At most, such a "partial incommensurabilty" argument calls into question the degree

tion problems can become so severe as to cause first-party insurers to withdraw coverage. See Baker, 75 Tex L Rev at 253 (cited in note 34) (noting that "refusal to insure" was the "first resort" of nineteenth-century insurers for types of coverage likely to create moral hazard); Mark V. Pauly, The Economics of Moral Hazard: Comment, 58 Am Econ Rev 531, 535 n 3 (1968) (suggesting moral hazard "as an explanation of why certain types of expenses are not insured commercially"). But see Shavell, 93 Q J Econ at 546-50 (cited in note 40) (demonstrating a model where some level of insurance will be offered despite total inability to observe conduct of insured).

61 See Miller $v$ Willbanks, 8 SW3d 607, 613 (Tenn 1999) (adopting "majority approach" of allowing jury to find severe emotional distress based on subjective testimony alone); Rodrigue $z$ Consolidation Coal Co, $206 \mathrm{~W}$ Va 317, 524 SE2d 672, 681 (1999) (holding that jury could find NIED based on plaintiff's testimony about his emotional state).

62 See Croley and Hanson, 108 Harv L Rev at 1850 (cited in note 3) (recognizing problems of proof for ex post emotional injuries).

63 For a mathematical demonstration, see Shavell, 93 Q J Econ at 546-49 (cited in note 40) ("[T]he level of [efficient] coverage approaches full coverage as the cost of taking care tends to zero.").

64 See, for example, Munn v Algee, 924 F2d 568, 574 (5th Cir 1991) (holding decedent's refusal to accept life-saving blood transfusion because of Jehovah's Witness beliefs to be unreasonable failure to mitigate).

65 Indeed the common law system of remedies is built on the assumption that money compensates for loss. 
of moral hazard in emotional distress liability, not its existence. In effect, "partial incommensurability" serves the function of an insurance copayment, ${ }^{66}$ whereby the insured bears part of the cost of his injury. Copayments limit moral hazard, but unless the copayment is 100 percent, it cannot eliminate it. ${ }^{67}$ Thus, even if, as the incommensurability thesis would suggest, people have private incentives to take every reasonable measure to reduce their emotional distress, the mitigation principle still would play an important role in establishing the proper level of damages. ${ }^{68}$

Moral hazard, like most microeconomic theories, is based on the idea of substitutability. ${ }^{69}$ People derive utility from a combination of things, such as physical health, economic prosperity, and emotional tranquility. One can maintain one's original level of utility after losing some of any of these elements by gaining more of some other element. Emotional distress may be incommensurable with money in the sense of replacement value: perhaps the damages award will not allow one to actually "buy back" one's previous emotional state. "However, emotional distress damages can have a substitution value equal to the injury - that is, they return plaintiff to his original indifference curve.

66 See Part IV.A.1 (discussing role of copayments in controlling moral hazard).

67 For example, a plaintiff's expected recovery is reduced by attorney's fees, and the likelihood that the case will settle for a sum less than the highest possible value of the claim. See Priest, 96 Yale L J at 1556 (cited in note 35). The costs of obtaining compensation through the legal system serve as a copayment or deductible mechanism for tort insurance, which might reduce the moral hazard but not eliminate it. These costs do not seem to reduce moral hazard significantly. These same costs, or their analogues, exist in the first-party insurance system, where the insurer does not pay on all claims and often negotiates to pay a sum less than what the claimant originally demanded. See id. However, despite these costs that might control moral hazard, firstparty insurance does not cover emotional injuries, largely because of moral hazard. See id at 1553; Randall R. Bovbjerg, Frank A. Sloan, and James F. Blumstein, Valuing Life and Limb in Tort: Scheduling "Pain and Suffering," 83 Nw U L Rev 908, 933-34 (1989) (describing how moral hazard prevents first-party insurers from writing policies to cover any intangible harms).

68 See Cass R. Sunstein, Incommensurability and Valuation in Law, 92 Mich L Rev 779, 796 (1994) ("Incommensurability occurs when the relevant goods cannot be aligned along a single metric without doing violence to our considered judgments about how these goods are best characterized."). Incommensurability could argue against compensation for emotional injuries. If defendants must pay money that fails to make good plaintiffs' emotional injuries, and the cost of this liability will be reflected in the higher cost of products or services, then people are being forced to cross-subsidize insurance that the plaintiffs would not choose to purchase ex ante. See Alan Schwartz, Proposals for Products Liability Reform: A Theoretical Synthesis, 97 Yale L J 353, 362-77 (1988).

69 The merits of this and other fundamental economic assumptions (like rational actors) that underpin moral hazard are beyond the scope of this Comment.

70 Yet money may help improve future emotional states, if spent in ways that bring comfort, peace of mind, or joy. 


\section{Moral Hazard in Various Emotional Distress Contexts Absent a Mitigation Rule}

In the absence of a mitigation rule, the severity of moral hazard varies across different legal categories of emotional distress liability." This discussion assumes that given a level of emotional distress damages $(D)$ caused by an injury, plaintiff's failure to mitigate results in a level of unmitigated distress $\left(D^{\prime}\right)$ at least as high as the original level of distress. In deciding whether or not to mitigate, plaintiff chooses between two damage levels: $D$ (which is constant) and $D^{\prime}$ (whose value plaintiff controls), with $D^{\prime}$ greater than or equal to $D$. The level of moral hazard equals $D^{\prime}-D$.

A crucial aspect of moral hazard absent a mitigation rule is the effect of plaintiff's level of distress on the probability of success at trial $(p){ }^{n}$ It is important to remember that failing to mitigate is not the same thing as feigning distress: when an injured plaintiff fails to mitigate his distress, his subjective level of emotional injuries may actually increase. Thus in the absence of a mitigation rule, a properly instructed jury would treat $D^{\prime}$ as the actual consequence of defendant's wrongdoing and grant full recovery.

1. Moral hazard in consequential damage cases.

A plaintiff can recover for emotional distress, no matter how slight or fleeting, when it stems from an independent, non-emotional tort. ${ }^{73}$ This suggests that when plaintiff's initial level of emotional distress, $D$, is zero (or very small), he has a relatively strong incentive not to mitigate and allow $D^{\prime}$ to increase. Because of the diminishing marginal costs to litigation, the cost of adding the $n$th damages claim to a tort suit that would be filed anyway is relatively small in relation to the cost of the litigation. Thus the move from $D=0$ to $D^{\prime}>0$ will likely increase the expected value of the suit, because the increase in expected recovery will exceed the marginal cost of adding the distress claim to a complaint.

To be sure, most physical injury torts, a subset of consequential distress cases, will be handled by contingency-fee attorneys, ${ }^{74}$ so in

71 See Part II.A.

72 Some models suggest that $p$ will likely be greater than 0.5 in litigated emotional distress cases. See Keith N. Hylton, Asymmetric Information and the Selection of Disputes for Litigation, $22 \mathrm{~J}$ Legal Stud 187, 188 (1993). Where one party has an informational advantage, that party should have a high win rate at trial. See id at 199 . In emotional distress cases, the plaintiff has an informational advantage with respect to a crucial element of the case-the effects of defendant's actions. Where the plaintiff's level of care influences the size of the injury, the plaintiff also has an informational advantage. See id at 202.

73 See text accompanying notes $4-13$.

74 See Samuel R. Gross and Kent D. Syverud, Don't Try: Civil Jury Verdicts in a System 
such cases the plaintiff does not directly face the marginal cost condition. However, the attorney must still take into account the costs of litigation. Thus the plaintiff's failure to mitigate may determine whether an attorney accepts the case in the first place. ${ }^{75}$ If plaintiff's failure to mitigate when $D=0$ (or very small) increases the value of the total claim by more than the (small) marginal cost borne by the attorney for adding the claim to the tort suit, the representation will become more attractive to the attorney ex ante.

When $D>0$, the private incentives not to mitigate diminish relative to $D=0$, but certainly do not disappear. The moral hazard should remain constant for all $D>0$. As a doctrinal matter, the size of $D^{\prime}$ should not affect the probability of establishing liability at trial. At most, it could affect the probability of recovering any given level of emotional distress damages themselves or the bargaining range for settlement. Thus $p$ should stay constant across all positive levels of emotional distress.

\section{Intentional infliction of emotional distress.}

The law requires that a plaintiff have severe emotional distress for him to prevail on an intentional infliction claim. ${ }^{76}$ Thus severity does not just determine the amount of damages, it determines whether plaintiff has a cause of action. Severity is a jury question. In the absence of a mitigation rule, the severity requirement exacerbates moral hazard, especially when the initial $D$ is near the severity threshold.

The severity rule creates a tipping effect: on one side of the line, plaintiffs get full recovery; on the other side, none. Thus plaintiffs near this threshold will have strong incentives to let their damages mount at least until the point where they think they are comfortably inside the severity zone. ${ }^{77}$ Once $D^{\prime}$ rises above what plaintiff believes to be the severity cutoff, his incentives become those of the consequential damages plaintiff discussed above. This suggests that moral hazard will be most acute at different levels of $D$ in IIED than in consequential cases-low levels for consequential damages and levels around the severity threshold for IIED. Furthermore, since IIED can be an independent tort, there are no economies to litigation when it is the plaintiff's sole cause of action. The marginal cost of bringing the distress

Geared to Settlements, 44 UCLA L Rev 1,15-18 (1996) (presenting empirical evidence that "contingent fees are essentially the only mode of payment in personal injury cases").

75 See Jonathan T. Molot, How U.S. Procedure Skews Tort Law Incentives, 73 Ind L J 59, 82-85 (1997) (discussing attorney incentives in choosing cases under contingent fees).

76 See Miller $v$ Willbanks, 8 SW3d 607, 612-13 (Tenn 1999) (explaining requirement that plaintiff have severe distress). See also Part I.A.2.

77 Because "severity" is not an objective cutoff but a vague standard, even plaintiffs with only colorably severe injuries might not be sure if they are within the recovery zone. 
claim equals the total cost of the litigation. This takes away the extra incentive faced by consequential distress plaintiffs to not mitigate.

\section{Negligent infliction of emotional distress.}

In the absence of a mitigation rule, the recent judicial movement in NIED cases from rule-bound, categorical proxies for severity to a subjective severity standard might exacerbate moral hazard problems. The categorical approach to NIED liability allows plaintiffs to recover only if their injury falls into predetermined classes of cases that the courts have deemed likely to result in real and severe distress. ${ }^{78}$ Thus the categorical approach limits moral hazard in an obvious way: if a plaintiff does not fall into one of the preexisting categories, he will have no chance of recovering regardless of how high he lets his damages mount. Thus he will take optimal mitigation measures. In other words, when there is no insurance, there is no moral hazard. Thus, the category-based limitations on recovery cabin moral hazard far more effectively than the open-ended subjective approach.

\section{THE DIfFICULTY OF CRAFTING STANDARDS FOR THE MITIGATION DEFENSE}

The de facto exemption of emotional distress from the mitigation rule creates moral hazard, resulting in systematic overcompensation of plaintiffs. Applying the mitigation rule would, ideally, be the first response to this problem. But developing judicially administrable standards of reasonableness for mitigation turns out to be much harder than determining that, in theory, the defense should be available. ${ }^{79}$ Indeed, the difficulty of implementing mitigation in the emotional distress context may explain why courts have avoided the issue.

This Part assesses psychiatric mitigation and willpower mitigation, the two most likely paradigms for reasonable mitigation. This Part finds the former solution unsatisfactory because of concerns about autonomy, confidentiality, and the possibility that it would merely replace one form of moral hazard with another. The subjective and intangible nature of willpower mitigation, on the other hand, makes it judicially unadministrable.

\section{A. The Medical Analogy-Psychiatric Mitigation}

Most of the cases that touch on the issue of mitigating emotional distress assume that it would involve psychiatric therapy and medica-

79 See Epstein, Torts $\S 17.7$ at 448 (cited in note 29) ("Stating the mitigation principle is one thing, applying it is another."). 
tion. $^{80}$ The gravitation towards psychiatric mitigation shown in these opinions should be no surprise, given that the recent expansion of emotional distress liability has often been justified by advances in medical knowledge. ${ }^{81}$ Furthermore, the psychiatric mitigation standard suggests itself as an obvious extension of the well-elaborated rules governing the medical mitigation of physical injuries. ${ }^{82}$ However, psychiatric mitigation raises unique problems of autonomy, second-order moral hazard, and privacy that medical mitigation usually does not.

\section{Autonomy.}

Plaintiffs with physical injuries cannot unreasonably delay seeking treatment, ${ }^{83}$ and must generally follow their physician's advice. The reasonableness determination becomes dicey when the proposed mitigation could itself have extremely unwelcome consequences, although mere discomfort or annoyance must be tolerated. ${ }^{85}$ So while courts generally find undergoing minor surgery to be reasonable ${ }_{87}^{86}$ mitigation need never entail life-threatening or very painful surgery. Furthermore, courts will generally not reduce plaintiffs' recovery for refusing procedures that could fundamentally alter their lives or per-

80 The only explicit jury instruction on emotional distress mitigation clearly contemplates psychiatric mitigation. See Musa v Jefferson County Bank, 233 Wis 2d 241, 607 NW2d 349, $352 \mathrm{n} 7$ (Wis App 2000), pet for rev granted, 237 Wis 2d 251, 616 NW2d 114 (2000). See also cases cited in notes 53-55 and 92-93.

81 See, for example, Corgan v Muehling, 143 Ill 2d 296, 574 NE2d 602, 609 (1991) (noting that the "mental health care field [has] made significant improvements in the diagnosis, description, and treatment of emotional distress"); David J. Leibson, Recovery of Damages for Emotional Distress Caused by Physical Injury to Another, 15 J Family L 163, 190-211 (1977) (describing medical advances that warrant expanded recognition of independent emotional distress torts).

82 See, for example, Salas v United States, 974 F Supp 202, 211-12 (W D NY 1997) (analogizing to physical injury/medical mitigation precedents in an emotional distress case); Jacobs $v$ New Orleans Public Service, Inc, 432 S2d 843, 846 (La 1983) (applying medical mitigation rules to emotional distress, but holding that plaintiff was not unreasonable in refusing psychiatric treatment since it would leave her penniless). See also Shipley, Annotation, 62 ALR 3d at $70 \S 13$ (cited in note 29) (citing as an extension of the medical mitigation rules "the few cases involving a claim that plaintiff should have submitted to psychiatric treatment to mitigate damages").

83 See Shipley, Annotation, 62 ALR 3d at $70 \S 13$ (cited in note 29) (discussing plaintiff's duty to mitigate in cases involving mental and nervous conditions).

84 See Tabieros v Clark Equipment Co, 85 Hawaii 336, 944 P2d 1279, 1316 (1997) (allowing jury instruction predicating mitigation on following prescribed course of medical treatment).

85 See Lobermeier v General Telephone Co of Wisconsin, 119 Wis 2d 129, 349 NW2d 466, 477 (Wis 1984). See also text accompanying notes 31-33.

86 See, for example, Troppi v Scarf, 31 Mich App 240, 187 NW2d 511, 519 n 11 (1971) (noting willingness to allow surgical procedures only if routine).

87 See Lobermeier, 349 NW2d at 474-75 (holding that plaintiffs need not mitigate physical injuries if the treatment is hazardous or not "reasonably within [the victim's] means"); Shipley, Annotation, 62 ALR $3 d$ at $70 \& 5$ (cited in note 29 ). 
sonality. ${ }^{88}$ Some choices are so intimate that the law will not entangle them with mitigation.

An excellent illustration of the difficulty courts have in dealing with particularly delicate avenues of mitigation is the new tort of "wrongful life," where plaintiff becomes pregnant after undergoing a botched sterilization by defendant physician. In these cases, plaintiff seeks damages for the cost of giving birth to and raising the unwanted child. Defendants often argue that plaintiff could have almost fully mitigated by getting an abortion or putting the unwanted child up for adoption. Most courts reject this mitigation standard as being overly invasive. ${ }^{89}$ Thus the law attempts to avoid defining reasonableness in a way that might pressure a plaintiff "to make an unwanted life choice solely to minimize [defendant's] losses."

Psychiatric treatment may well be a "life choice" with which courts would not wish to involve themselves. Antidepressants, antipsychotics, and other psychotropic drugs have powerful, and often unpleasant, side effects." And as the Second Circuit has noted, the efficacy of psychiatric treatment in healing emotional distress remains controversial. ${ }^{92}$ One court in an emotional distress case pointed to the common Prozac side effects of jumpiness, sleepiness, and confusion as reasons that a plaintiff could reasonably shy away from such medication. $^{93}$ To be sure, in terms of physical discomfort, such side effects cannot exceed those of the procedures held to be reasonable in physical injury mitigation. Psychiatric mitigation also differs from other

88 For example, a court has held that as a matter of law, an injured plaintiff does not fail to mitigate if he refuses an operation that might render him impotent. See Cannon $v$ New Jersey Bell Telephone, 219 NJ Super 304, 530 A2d 345, 351 (NJ Super App Div 1987).

89 See Fassoulas $v$ Ramey, 450 S2d 822, 829 (Fla 1984) (suggesting that as a matter of law requiring abortion or adoption as mitigation is unreasonable); Boone $v$ Mullendore, $416 \mathrm{~S} 2 \mathrm{~d} 718$, 723 (Ala 1983) ("[C]ourts ... have rejected the arguments that parents should choose among the various methods of mitigation-adoption, abortion, etc."); Troppi, 187 NW2d at 520 (holding that, as a matter of law, "no mother, wed or unwed, can reasonably be required to abort (even if legal) or place her child up for adoption"). A few jurisdictions have held that reasonable mitigation does include abortion and adoption. See, for example, Hartke v McKelway, 707 F2d 1544, 1557 n 15 (DC Cir 1981) (citing precedents and academic commentary).

90 See Epstein, Torts $\$ 17.7$ at 448 (cited in note 29 ).

91 See Peter D. Kramer, Listening to Prozac (Viking 1993). See also A Variety of Drugs Available, Morning Star 1D (Sept 26, 2000) (reporting that side effects of selective serotonin reuptake inhibitors include sexual dysfunction in at least 30 percent of patients, and noting possible connection between Prozac and suicide); Phil Galewitz, Prozac's Reign as Top Drug Ending, Associated Press (Mar 7, 2000) (reporting that some doctors link Prozac to self-destructive and suicidal behavior); David Healy, Good Science or Bad Business?, The Hastings Center Report 19, 21 (Mar 1,2000) (discussing evidence that Prozac might increase suicide rates).

92 See Miner $v$ City of Glens Falls, 999 F2d 655, 663 (2d Cir 1993) (holding, in the $\$ 1983$ case of a small town policeman fired after he became a Jehovah's Witness and refused to carry a gun, that "there was no reason to expect that medicines or counseling could dispel the trauma of losing ... one's professional standing in the community, one's home and one's income").

93 See Salas v United States, 974 F Supp 202, 211-12 (W D NY 1997). 
medical mitigation because the side effects express themselves in the mind and mood of the patient, and thus can be seen as greater usurpations of autonomy.

An example of the difficulties in fitting emotional distress into the standard medical mitigation paradigm arose when a defendant demanded that plaintiff's emotional distress damages be reduced because of his refusal to undergo the electroshock treatments his doctor had strongly recommended. ${ }^{95}$ A Louisiana appellate court did not question the "undoubted value and benefit" of electroshock. ${ }^{96}$ However, the court expressly set aside the standard medical mitigation rules, which it believed were inapplicable to "the most misunderstood field of medicine, i.e., treatment of the mind." explain that psychiatric treatment differs from conventional surgery because it is "designed to work a change on [one's] personality." Thus even if the treatment has a positive expected value, the decision to undergo it might be one of those life choices-like undergoing an abortion or risking the loss of a major bodily function - that the law refuses to investigate or second guess.

\section{The problem of the "merry mitigator."}

Psychiatric mitigation might also create a second-order moral hazard problem while attempting to solve the primary one. Standard mitigation involves actions that no one would undertake in the absence of a genuine injury. For example, no one undergoes an invasive surgery just for fun. Yet counseling and medication for emotional problems, especially antidepressants like Prozac and Zoloft, have an independent consumption value. People who have not suffered an injury leading to mental distress want these goods and services anyway." And, these elective treatments do not come cheap.

94 While some surgical treatments might also involve psychoactive drugs, psychiatric mitigation would have a far greater effect on a plaintiff's mental state. Unlike drugs administered in surgery, whose effects on personality are incidental, antidepressants and their ilk are taken over a long period of time, and thus have more durable and pronounced effects on the personality. Indeed, unlike other medications that can affect mood, Prozac and similar drugs are specifically designed to change the patient's brain chemistry so as to cause substantial changes in his consciousness and day-to-day personality. See David DeGrazia, Prozac, Enhancement, and Selfcreation, 30 Hastings Center Rep 3440 (2000) (discussing the effects of Prozac on one's personality).

95 See Dohman v Richard, 282 S2d 789, 793 (La App 1973) (holding reasonable plaintiff's refusal of treatment despite the fact that the doctor vouched that electroshock had as much as a 90 percent chance of improving the plaintiff's condition).

96 Id at 794.

97 Id at 793.

98 Id.

99 Millions of people take antidepressants as "cosmetic psychopharmocology" to enhance social traits or create a sense of well-being rather than to treat abnormal mental states. See 
Because defendants must pay for expenses incurred in mitigation, the millions of tort victims who desire psychiatric medication for "cosmetic" purposes could claim to mitigate by using these drugs, and thus get "free" psychiatric services. Creating a psychiatric mitigation standard would open new avenues for fraud: plaintiffs might assert emotional distress damages and claim to fully "mitigate" nonexistent distress by taking the antidepressants they would want to take anyway. Of course, defendants could challenge the validity of such supposed mitigation. Yet defendants might be reluctant do to so. If they pay for the drugs, the distress claim is resolved. But if they refuse to do so, they must contest the underlying distress claim, which, since it usually involves discovery and litigation costs, may be more expensive.

Moreover, emotional distress suits have an extremely high variance in damage awards. A risk-averse defendant who knows the plaintiff's distress is specious might choose to pay the mitigation bill anyway. The merry mitigator problem resembles the classic moral hazard problem of "goldbricking," where, for example, physical injury plaintiffs undergo a needed surgical procedure in a luxurious hospital suite on the French Riviera. However, the merry mitigator problem may be both more severe and harder to police than goldbricking. The primary difference is that because there is no consumption value in surgery, few people will submit to it just to get a luxurious hospital suite. However, millions of people want antidepressants, and under a psychiatric mitigation standard, they would not have to submit to an unwanted procedure to get what they desire. This relates to the policing problem. Goldbricking can be policed because there are obvious objective grounds on which to distinguish the legitimate "bricks" from the illegitimate "gold." (It is easy in practice to separate French Riviera hospitals from less hospitable ones.) The merry mitigator, on the other hand, does exactly what a distressed mitigator would do under a psychiatric mitigation standard-take antidepressants. The brick is the gold.

Kramer, Listening to Prozac at XVII-XVIII (cited in note 91). As a practical matter, such people have little difficulty getting prescriptions. Moreover, such drugs can now be prescribed for conditions wholly unrelated to mental illness, such as premenstrual syndrome. See Galewitz, Prozac's Reign as Top Drug Ending, Associated Press (cited in note 91) (reporting that Prozac is widely used for "simply making people feel good"); Sandra M. Foote and Lynn Etheredge, Increasing Use of New Prescription Drugs: A Case Study, Health Affairs 165, 166 (July-Aug 2000) (describing antidepressants as fastest growing category of therapeutic drugs, with 120 million prescriptions written in 1988, and citing growing array of non-mental health uses for the drugs as being a major factor). 
3. Privacy issues make psychiatric mitigation problematic.

When uninsured individuals seek psychiatric treatment, they enjoy doctor-patient confidentiality. Yet psychiatric treatment as mitigation would become part of a public record, and could thus be discovered by potential employers, business partners, spouses, and lovers. As a result, psychiatric mitigation in the tort context imperfectly mimics the incentives unindemnified people with distress would have to seek treatment. Having the treatment a matter of public record might have reputation costs, as well as possibly reducing the effectiveness of the treatment. ${ }^{100}$ Thus, there is reason to think that the costs of psychiatric mitigation, including secrecy and reputation costs, outweigh any possible benefits in a large number of cases.

\section{B. Mitigation through Willpower}

1. What is "willpower mitigation"?

Those skeptical of the efficacy or legitimacy of psychiatric treatment might favor a different mitigation paradigm-exercising willpower and self-control. ${ }^{101}$ People have some degree of control over their emotional states. ${ }^{102}$ Willpower mitigation certainly avoids many of the problems of psychiatric mitigation. Furthermore, willpower costs far less than psychiatry.

However, only a couple of decisions appear to endorse a willpower standard over a psychiatric one. ${ }^{103}$ In the principal case, plaintiff flight attendant suffered emotional distress when his airplane crashed, leaving him badly burned. ${ }^{104}$ The district court's opinion emphasized plaintiff's sustained efforts to "cope" with his emotional distress, praising him as "a man of substantial resolve." "In particular, the court noted that he "forced himself" to fly in airplanes again and he took up

100 See Deborah A. Zarin, et al, Characteristics of Health Plans That Treat Psychiatric Patients, Health Affairs 226, 229 (Sept-Oct 1999) (referencing a study showing that 20 percent of health plan patients choose to pay for their own psychiatric treatment to protect their confidentiality).

101 See Salas v United States, 974 F Supp 202, 212 (W D NY 1997) (noting the "general belief that drugs cannot alleviate emotional difficulties and that such problems must be overcome by one's own willpower").

102 An array of everyday idioms suggests the wide acceptance of the willpower perspective: not wallowing in one's misery, cheering oneself up, accentuating the positive, getting a grip, etc.

103 See In re Air Crash Disaster at Charlotte, NC on July 2, 1994, 982 F Supp 1101, 1112 (D SC 1997) (finding that plaintiff did take reasonable steps to mitigate emotional distress damages by choosing to make "major efforts in other ways ... [including an] attitude of self-reliance and determination").

104 See In re Air Crash Disaster at Charlotte, NC, 982 F Supp at 1105, 1110.

105 Id at 1105. 
a hobby that "gives him a sense of purpose." of damages, the court stated:

$[\mathrm{T}]$ he court finds that Mr. DeMary's choice not to take antidepressant medications is not a wholly unreasonable choice. He has, instead, made major efforts in other ways and obviously declined the reliance on medication based on the same attitude of selfreliance and determination that have brought him this far in his recovery. Therefore, the court does not find this personal choice to be a failure to mitigate damages under the present circumstances.

\section{The problems of a willpower mitigation standard.}

The overwhelming flaw with a willpower standard is that, like emotional distress itself, it is subjective and not necessarily verifiable. Other difficult mitigation judgments, like whether a wrongfully discharged plaintiff took reasonable efforts to find a new job, may be subjective, but they have obvious and well-settled objective correlates, like mailing out resumes and going to interviews. Willpower mitigation, on the other hand, does not lend itself to judicial administration - it would be an unguided, freeform jury inquiry, based primarily on plaintiff's credibility. The inquiry would be made particularly difficult by the fact the willpower probably varies considerably across individuals, so no one standard could capture "reasonableness."

Furthermore, the plaintiff possesses all the information on whether he mitigated, and yet the defendant bears the burden of proof. Thus it would be exceedingly difficult for defendants to know whether to raise the mitigation defense; litigation would be costly since the defense could never be disposed of on summary judgment; and it might turn out to be a practical impossibility for a defendant ever to prove that plaintiff did not try to exercise self-control. Thus a willpower mitigation standard would likely be a dead letter, and not a practical tool for restraining moral hazard.

\section{How to REDUCE MORAL HAZARD WITHOUT ADOPTING A MITIGATION RULE}

In the absence of a workable mitigation rule, courts and legislatures must turn to other solutions for the moral hazard problem. There are only two ways to reduce moral hazard in first- or third-party insurance: (1) observe the behavior of the insured and condition reimbursement on the appropriate level of care; or (2) limit the overall 
amount of reimbursement available. In tort insurance, the affirmative defense of failure to mitigate serves as the mechanism through which plaintiff's ex post care might be observed, and recovery conditioned on the exercise of care. But, as Part III has shown, emotional distress damages do not lend themselves to the application of workable mitigation standards. First-party insurers respond to moral hazard by providing less than full coverage against loss when observation of ex post care is either impossible, unreliable, or too expensive. ${ }^{108}$ The tort system must also turn to some form of partial compensation to reduce the moral hazard associated with emotional distress damages.

This Part considers possible alternatives to a mitigation rule to limit the moral hazard in emotional distress liability. Part IV.A considers limitations on the size of recovery, such as damage caps, floors, and multipliers. In general, such mechanisms may often relocate moral hazard instead of reducing it, and could not easily be applied to the independent emotional torts. Part IV.B discusses from a mitigation perspective the categories the common law has used to limit the scope of emotional distress liability, such as the requirement of a physical injury, physical manifestation, malicious intent, or, more recently, contemporaneous perception of the death of a family member. This "categorical approach," invented by courts to weed out trivial, feigned, and imagined claims, should be used for an independent reason. The categorical approach best controls moral hazard because it uses circumstances beyond plaintiffs' control as a proxy for their emotional distress. Moreover, by preventing recovery in cases where the initial distress is likely to be small, the categorical approach eliminates the cases that might cause the most moral hazard while allowing recovery for plaintiffs who have been most seriously injured.

\section{A. Limiting Damages}

1. Copayments and deductibles.

Ideally, tort law would respond to hard-to-monitor moral hazard the same way first-party insurance does - with a system of copayments and deductibles. In other words, the jury would determine the plaintiff's level of emotional distress, but damages would only be granted for some percentage of the distress. The percentage would be higher in contexts where moral hazard is likely to be greater. ${ }^{109}$ This is a radical

108 See Shavell, 93 Q J Econ at 544-46 (cited in note 40) (showing that insurers will not provide full coverage when they cannot observe care, with the amount of coverage decreasing as observation costs increase).

109 See Part II.C. 
suggestion: the tort system does not in other contexts use coinsurance.

Emotional distress may not be the best context to pioneer a coinsurance scheme for third-party liability. Juries often use emotional distress damages as a substitute for punitive damages. ${ }^{111}$ Furthermore, some evidence suggests juries award emotional distress damages as a way of covering plaintiffs' legal fees. ${ }^{112}$ Thus, if juries know in advance the copayment percentage, they might simply adjust upwards their initial assessment of the distress level to compensate for the copayment.

Of course, judges could police this problem through remittitur. Yet remittitur is an imperfect solution. It only allows judges to set aside awards that are "so grossly disproportionate to any injury established by the evidence as to be unconscionable as a matter of law."113 And, courts are particularly reluctant to second guess emotional distress awards. ${ }^{114}$

\section{Damage ceilings and floors.}

Caps or ceilings are a popular tort reform measure, adopted in a great number of jurisdictions, usually by the legislature, ${ }^{115}$ but sometimes by the judiciary. ${ }^{16}$ Statutory damage limitations have been particularly popular for nonpecuniary damages ${ }^{117}$ and punitive damages. ${ }^{118}$

110 See Priest, 96 Yale L J at 1553 (cited in note 35) ("Third-party insurance through the tort system, in contrast [to first-party insurance], never incorporates deductibles or co-insurance to control victim moral hazard.").

111 See Daryl L. Wiesen, Note, Following the Lead of Defamation: A Definitional Balancing Approach to Religious Torts, 105 Yale L J 291, 294 (1995) ("[D]ue to the difficulty of determining 'actual injury' in intentional infliction of emotional distress cases, damages that are compensatory in name tend to be punitive in nature.").

112 See W. Kip Viscusi, Reforming Products Liability 114 (Harvard 1991) (discussing evidence that nonpecuniary damages usually comprise a proportion of total damage award roughly equivalent to a contingent fee percentage and hypothesizing that juries may be engaged in implicit fee shifting).

113 Koster v Trans World Airlines, Inc, 181 F3d 24, 34 (1st Cir 1999) ("We will not disturb an award of damages because it is extremely generous or because we think the damages are considerably less.").

114 See Tompkins v Cyr, 202 F3d 770, 783 (5th Cir 2000) ("Our review of a damage award for emotional distress and mental anguish is conducted with deference to the fact-finder because of the intangibility of the harms suffered.").

115 See Priest, 96 Yale L J at 1587 (cited in note 35) (noting that forty-two states have recently adopted some form of tort reform, generally damage caps on both noneconomic and punitive damages).

116 The Supreme Court of Canada has adopted caps on nonpecuniary damages by decision. See Andrews v Grand \& Toy Alberta, Ltd, 83 DLR 3d 452, 477-78 (1978) (holding that victims of nonpecuniary loss are "entitled to a more or less equal measure of compensation for similar nonpecuniary loss").

117 This broad category includes everything from pain and suffering to loss of consortium. Limitations on nonpecuniary recovery are often imposed only in certain tort contexts, particularly medical malpractice or products liability. See Neil K. Komesar, Injuries and Institutions: Tort Reform, Tort Theory and Beyond, 65 NYU L Rev 23, 59 n 72 (1990). 
The advantages and disadvantages of these reforms have been extensively discussed, ${ }^{119}$ and this Comment does not take a position on this wider issue. However, caps might not be very useful in combating moral hazard in emotional distress.

As substitutes for a mitigation rule, the weakness of caps is that they do not affect moral hazard at all for all $D^{\prime}$ below the statutory ceiling. Damage caps (unless they are very low) would only limit moral hazard at the high end, but in consequential damages cases, moral hazard seems most severe at the low range of initial distress. ${ }^{120}$ Thus in consequential cases, the cap would have to be set very low (relative to current nonpecuniary damage caps) to have any effect on most cases. On the other hand, a damage floor might cut out the morally hazardous low end of distress in consequential cases."

However, a floor, like any all-or-nothing limitation, would introduce the subjective severity problem encountered in the independent emotional torts, with plaintiffs having an incentive to not mitigate until $D^{\prime}$ clears the statutory floor. This problem can be partially remedied by only allowing recovery for the portion of damages above the floor. Thus if the floor is $\$ 20,000$ and plaintiff has $\$ 25,000$ in damages, he recovers $\$ 5,000$. This also has the advantage of reducing some of the all-or-nothing unfairness of statutory cutoffs. However, it amounts to a deductible, with the problems discussed in Part IV.A.1. Perhaps the best of both worlds would be a floor to eliminate the low-end moral hazard associated with consequential distress, coupled with a ceiling to prevent juries from inflating their original damage figure to make up for the deductible that they know plaintiff will face.

Ceilings and floors would work differently when applied to the independent torts because the severity requirements themselves act as a floor requirement. Thus floors would be superfluous. Caps, however, seem to contradict the general policy behind the independent torts,

118 See Steven R. Salbu, Developing Rational Punitive Damages Policies: Beyond the Constitution, 49 Fla L Rev 247, 297-98 (1997) (discussing various states' statutory caps and multipliers to limit punitive damages).

119 See, for example, Viscusi, Reforming Products Liability at 115 (cited in note 112) (discussing inequities caused by statutory caps); Komesar, 65 NYU L Rev at 53-55 (cited in note 117) (discussing effect statutory caps have of relocating damage decisions from juries, who are hard to influence ex ante, to legislatures, who can be lobbied ex ante by powerful interest groups); Bovbjerg, Sloan, and Blumstein, $83 \mathrm{Nw}$ U L Rev at 957-58 (cited in note 67) (discussing arbitrariness of damage caps).

120 See Part II.C.1.

121 See Bovbjerg, Sloan, and Blumstein, $83 \mathrm{Nw}$ U L Rev at 959-60 (cited in note 67) (recommending "flexible ranges" created by combination of floors and ceilings as a preferable alternative to simple caps). Some commentators have also suggested using a combination of ceilings and floors. See American Law Institute, 2 Reporters' Study: Enterprise Responsibility for Personal Injury 221-30 (1991) (recommending combination of ceilings and floors for noneconomic tort damages, with floor designed to preclude minor claims). 
which is to grant full recovery for serious emotional injuries. Thus neither caps nor floors seem satisfactory in the independent tort context.

\section{Damage multiples and schedules.}

Damage multiples may offer a promising way of controlling moral hazard for consequential distress, but would be harder to implement for intentional torts. Statutory caps and floors suffer from the problem that they might only shift or relocate the incidence of moral hazard. But because moral hazard arises only when plaintiff's level of care affects the amount of his recovery, tying the damage measure to something beyond plaintiff's control will be a powerful way of preventing moral hazard. If emotional distress compensation is independently fixed, it will not affect plaintiff's choice between $D$ and $D^{\prime}$, since recovery is independent of $D^{\prime}$.

The multiples approach would set emotional distress damages at some ratio of the underlying compensatory award. ${ }^{122}$ In the punitive damages context, multiples of compensatory damages have been criticized as mixing apples and oranges. ${ }^{123}$ The opposite is true of multiples for emotional distress, since compensatory and emotional distress damages both seek to compensate the plaintiff. Indeed, the ratio plan would also fit well with the judicial intuition that the severity of distress is positively correlated with the severity of the underlying injury. The ratio need not be constant: ${ }^{124}$ thus courts can have the multiple increase as consequential damages increase. ${ }^{125}$

However, with IIED and NIED, there are no underlying nonemotional damages, and thus nothing to multiply. Still, plaintiffs often plead the independent emotional torts alongside other independent torts, like sexual harassment or wrongful discharge. In such cases, courts could use a reverse multiplier approach, where the emotional distress recovery would not be allowed to exceed some fixed proportion of the recovery on the independent nonemotional claims. Still, this plan could not be generally applied because IIED and NIED are

122 See Salbu, 49 Fla L Rev at 297-98 (cited in note 118) (discussing varieties of damage ratio regimes for punitive damages). Ratios can be used either as fixed levels of recovery, in which case they resemble schedules of the sort used in workmen's compensation, or as a more flexible version of damage caps. The present discussion sees multiples as fixing recovery, rather than capping it.

123 See id at 299-300 (criticizing multiples because punitive damages "bear[ ] no logical proportional relation to the amount of the compensatory damages award," since the former seeks to deter while the latter seeks to compensate).

124 See Bovbjerg, Sloan, and Blumstein, $83 \mathrm{Nw}$ U L Rev at 940 (cited in note 67) (proposing comprehensive scheduling regime for nonpecuniary injuries with nonlinear severity multiplier).

125 But see id at 939 n 153 (criticizing such simple form of scheduling for, among other faults, creating "too great an incentive for malingering and other forms of moral hazard which would increase economic harm" and thus the fixed noneconomic damage award). 
so often the sole claims in a suit, and the uniformity engendered by general application is seen as one of the key virtues of any fixed recovery scheme.

Schedules are a more sophisticated and elaborate (and administratively cumbersome) version of damage multiples, where various factors combine to yield fixed recoveries for various classes of injuries. Workmen's compensation remains the paradigmatic case of legislative scheduling, but some scholars have developed a proposed scheduling model for nonpecuniary injuries. ${ }^{126}$ This scheduling scheme effectively addresses moral hazard concerns by basing award levels on "objective factors reasonably related to non-economic loss," plaintiff's ex post control.

The primary weakness of the proposed matrix from a mitigation perspective is that the specific damage valuations are calculated based on past jury verdicts. ${ }^{128}$ This method succeeds in addressing the primary concern of its proponents - reducing variance in awards by taking them out of the hands of the jury. ${ }^{129}$ But acknowledging the mitigation problem in emotional distress shows that not only is the variance too high, but also so is the mean. Thus basing award values on past verdicts would simply perpetuate the overcompensation caused by unmitigated moral hazard. Yet without past jury verdicts as a guide, there is no obvious way to establish matrix values without risking arbitrariness and error. And as with multiples, applying the schedule to IIED and NIED seems incoherent.

\section{B. Limiting Availability of Emotional Distress Recovery}

Recognizing the moral hazard problems inherent in emotional distress suggests courts should not expand the scope of such liability any further, for doing so would only expand the scope of the moral hazard. The mitigation problem lends additional support to the posture of courts that have not recognized bystander liability, do not allow general NIED claims, require physical manifestation of injuries, and only grant consequential damages when parasitic to physical injuries. Further, the mitigation problem suggests that judges should reject efforts by plaintiffs to recover emotional distress damages in novel contexts. Finally, the mitigation problem suggests that courts that have already allowed a broad expansion of emotional distress liability

126 See id at $938-65$.

127 Id at 939 (suggesting the most appropriate objective factors to be considered are "the severity of the [economic] injury, the injured person's age, and the body part affected").

128 See id at 942 (suggesting "basing matrix values on the awards for nonpecuniary injuries of past juries, preferably as adjusted by the trial and appellate courts").

129 See id at 919-25 (presenting empirical evidence of high variability and explaining why it is a problem). 
should be open to defendants' efforts to partially undo some of this expansion by, for example, reintroducing the physical injury requirement. The weakness of such doctrinal limitations is that while they effectively contain the scope of the moral hazard problem, they do not at all reduce the severity of moral hazard in the sets of cases where liability will be allowed. Ideally, the doctrinal limitations on liability would limit it to sets of cases where moral hazard would be less severe.

Any solution that limits liability or recovery raises the question of whether in an attempt to rectify undesirable systematic overcompensation, the solution might cause systematic undercompensation. ${ }^{130}$ The answer to this is two-fold. First, the categorical approach does not deny recovery across the board, but rather attempts to focus on the types of cases where moral hazard would be the highest. By cutting out the most morally hazardous cases, while allowing full recovery in the rest, such a solution may overcompensate some individual plaintiffs but on a systemic level could outperform the status quo.

Second, even if the solution results in some systematic undercompensation, this might be preferable to overcompensation. Overcompensation leads to the unraveling of both first- and third-party insurance functions by aggravating the adverse selection problems inherent in insurance. ${ }^{131}$ Overcompensation, when reflected in the increased cost of the products, services, or activities that give rise to liability, means that people will have to "purchase" a higher level of insurance than they would prefer. Those for whom the difference in what they would pay and what they must pay is greatest will begin dropping out of the risk pool (by no longer using the product or service or engaging in the activity) ${ }^{132}$ As the low-value people drop out, the insurance premium must get progressively higher, because it reflects the value of compensation to the average member of the risk group. Thus overcompensation can, ironically, result in many people having no compensation at all because they have been priced out of the market. ${ }^{133}$

130 Of course, emotional distress law has always recognized that it should not attempt to compensate every emotional injury, and the current law, by not granting recovery for many types of distress (such as non-severe distress caused by negligence), recognizes that the goal of individual compensation must often be partially sacrificed to obtain better systemwide results.

131 See Priest, 96 Yale L J at 1540-41 (cited in note 35).

132 See id at 1574-77 (explaining unraveling in third-party insurance and offering empirical evidence of the phenomenon).

133 See id at 1564-65 (discussing how low-risk consumers, or those whose expected damages are lower than the average compensation, will stop using the product or service altogether, and using four-wheel drive vehicles as an example). 
C. Eliminating the Subjective Severity Requirement

Requiring plaintiffs' distress to be severe while making severity a jury question tends to exacerbate moral hazard in the absence of a mitigation rule. Creating more objective medical tests of severity, as some commentators have suggested, will not help: these methods may be useful in separating genuine from feigned distress, but the distress caused by failure to mitigate must be considered genuine. The older approach of using objective proxies, such as physical injury, based on the cause of the distress and the manner of its infliction would be more effective than a subjective severity standard. While plaintiffs' level of care can affect their level of distress, it cannot affect the source or type of the distress. Thus the jurisdictions that have not abandoned the physical injury requirement should not do so, and those that have should rediscover it. Moreover, this suggests that courts should adhere to the categorical approach in NIED, and strictly and carefully delimit the boundaries of those categories.

\section{CONCLUSION}

Emotional distress liability creates particular problems of moral hazard that courts have not yet taken into account. This moral hazard cannot be readily controlled with the standard judicial tool, the mitigation defense. The vagueness and subjectivity that permeate emotional distress recovery no doubt contribute to the difficulty in crafting an administrable mitigation rule. But absent such a rule, emotional distress invites moral hazard and leads to systematic overcompensation. To contain this moral hazard, courts should halt the expansion of emotional distress liability. Then courts should insist that emotional distress plaintiffs prove their distress by pointing to objective proxies, which do not depend on plaintiffs' ex post level of care, such as physical injury. 